\title{
Supervision of Human Resource Management during the Covid 19 Pandemic
}

\author{
Szelui Willy ${ }^{1}$, Oerban Attelie ${ }^{1}$ \\ Faculty of Economics and Business, University of Debrecen, Hungary
}

\begin{abstract}
Personnel management will demonstrate how businesses should recruit, develop, use, assess, and retain workers in terms of both amount (quantity) and kind (quality) The goal of this article is to implement a project assigned to one of the Entrepreneurship Courses during the Covid-19 Pandemic. The process of identifying and recruiting the personnel required by the company to become employees is known as recruitment. Vacancies, promotions, transfers, retirements, terminations, permanent disability, death, and labor turnover may need recruiting. A successful HR strategy requires the completion of many stages. Human Resource Planning (HRP) is a set of actions that a company does to anticipate future business and environmental needs. Human resource planning is required to fulfill the organization's requirements for specific jobs to be filled. The procedure includes identifying which jobs must be filled, the number of workers required, and when they will be required. In HR planning activities, job analysis has a tight connection with job analysis (Human Resources) Efforts to move and reorganize work activities in different groups are included in job design restructuring. Employee training is a long-term investment in workforce development that pays out handsomely. It's a technique/tool for executive management and growth.
\end{abstract}

Keywords: Human Resources, Management, Covid-19

Received: April 17, 2021

Revised: May 26, 2021

Accepted: June 16, 2021

\section{Introduction}

Personnel (human resources) management activities are specialized activities that are concerned with identifying the company's human resource requirements, both short-term and long-term, and putting those requirements into action. Personnel management is required to maximize the effectiveness of an organization's human resources. The objective is to create an efficient work unit for the company (Amah \& Ahiauzu, 2013). To do this, the study of personnel management will demonstrate how businesses should recruit, develop, employ, assess, and retain people in terms of both amount (quantity) and kind (quality).

Additionally, personnel management includes system design, employee preparation, staff development, career management, performance assessment, and employee pay, as well as positive employee relations. Human resource management encompasses all managerial choices and activities that have a direct impact on human capital (Jiang et al., 2012).

The explanation of the backdrop above enables the formulation of the issue to be established, specifically what is meant by personnel management, how to identify personnel requirements, and personnel-related difficulties.

The aim of this paper is to complete a job assigned in one of the Entrepreneurship Courses and to study the Entrepreneurship content in general (Lumpkin et al., 2009). And as for the material aims, they are to accomplish organizational goals effectively and to allow people to work to their full potential by using all of their skills, interests, and opportunities. 


\section{Definition of Personnel Management}

Human resources are the most valuable resource that a company can have (Personal). Individuals who provide their time, energy, creativity, skill, and effort to the organization's success. Personnel management that is carried out correctly will make a major contribution to the achievement of the objectives of the organization or business in question.

The process of dealing with different issues in the scope of employees, employees, laborers, managers and other workers to be able to support organizational or business operations in order to accomplish specified objectives is referred to as Personnel Management (Autry \& Daugherty, 2003). A continuous process, Personnel Management strives to provide an organization or business with the appropriate personnel who are put in the appropriate roles and who are available for those jobs whenever the organization requires them.

\section{Determination of Personnel Needs}

Determination of Personnel Requirements, also known as Human Resource Planning, is the process of evaluating and defining an organization's human resource requirements in order for the company to decide the actions that must be done in order to accomplish its strategic objectives (Armstrong, 2006). Apart from that, the significance of human resource planning is that it allows a company to see clearly into the future and foresee shortfalls in the necessary quality of employees.

There are many criteria for developing a successful human resource plan, the most important of which is a clear definition of the intended issue (DeCenzo et al., 2016; Barnett \& Davis, 2008). Compile and evaluate all of the information on human resources in the company. Explain in detail what job analysis (job analysis), organizational conditions, and human resource supply are all about. Make predictions about the present and future human resource condition. Make predictions about future human resource and technological advancements. Learn about government laws and policies, particularly those pertaining to labor, and apply them.

For effective human resource planning, steps must be taken such as clearly determining the quality and quantity of human resources, collecting complete data and information about human resources, grouping the data and information, then analyzing it, determining many alternatives that may be taken, selecting the best alternative from the several alternatives, informing employees of the selected plan so that it can be implemented, and finally implementing the selected plan successfully.

\section{Admission, Placement and Coaching Process}

\section{Recruitment}

The process of recruitment (employee procurement), requitment is the process of identifying and committing potential workers or candidates for prospective employees who are eligible to apply for positions as employees to a certain company (Brundage \& Koziel, 2010). This procedure starts with the recruitment of candidates and concludes with the submission of their application or applications. Once potential workers have been chosen, submit your information and wait for the results.

Recruitment is the process of identifying and recruiting the qualified candidates who will work for the company as workers. That is to say, recruiting is also the first step in the process of manpower procurement, which is the process of obtaining and attracting suitable individuals for job opportunities. 
This process starts with the recruitment of new candidates and concludes with the submission of applications, which results in a pool of applicants who will be chosen via a more advanced procedure, called the selection process, in the future.

The need for recruiting may arise for a variety of reasons, including job openings, promotions, transfers, retirements, terminations, permanent disability, death, and high turnover in the workforce (Compton, 2009). Because of a company's development, expansion, and diversification of its business operations, it may see an increase in job openings. Additionally, new openings may be created as a result of job respecification.

There are 2 (two) sources of recruiting available, which are as follows: Internal recruiting (recruitment from inside the organization), with the qualities of the workforce being well known, serving as a positive example for other workers and encouraging work excitement, may be completed more rapidly than external recruitment. External recruiting (hiring from outside the company), including features such as advertising, job placement offices (outsourcing), candidates suggested by current workers, and recruitment via schools/colleges

\section{Optional selec-tion}

Selection is the process of studying and choosing from a pool of candidates who have been acquired from a variety of sources in order to identify those who are the most qualified for the job being advertised (Ekwoaba et al., 2015). Application form completion, pre-interview, psychological assessment (Psikotest), health exam completion, in-depth interview completion, approval of the concerned manager's permission, and placement are some of the selection processes that are frequently utilized.

A selection tool is used to help the interviewer in the selection process in order to make it more efficient. Among the selection tools utilized are biodata to make the interview process easier, such as curriculum vitae, interviews, exams (knowledge, performance, health), and psychotests, among other things (intelligence, emotion, social relations, vitality, etc.)

\section{Orientation for New Employees}

New workers who have passed the selection process are provided with orientation, which includes new attitudes, value standards, and behavior patterns that the company/organization expects them to have after they have completed the recruiting process. Orientation is a followup activity that takes place after the recruitment process that is carried out by the company/organization for new employees who have passed the selection process.

\section{Process of Placement}

In the context of attaining organizational objectives, human resource planning (HRP) is a set of actions that are carried out to predict future business and environmental demands on the company and to fulfill the workforce requirements resulting from these circumstances. It is necessary to have human resource planning in place in order to fulfill the organization's requirements for filling certain jobs.

Human Resource planning may be divided into three categories. It is necessary to determine the number of jobs that must be filled, the skills that workers must possess in order to do the task, and the number of employees that will be required to complete the work. A thorough understanding of the labor market in which the prospective employee may be found Take into consideration the current circumstances of demand and supply for workers.

The following are the actions that may be taken in order to prepare an organizational planning document: Determination of the job specifications. Create job requirements that include the abilities required to carry out the responsibilities of the position. Calculate the number of 
workers that will be required at a certain time in the future. Consider the amount of workers who are now available to do a variety of tasks, followed by the number of individuals who need to be recruited and when they will be required to do so.

We may infer from the four fundamentals discussed above that the preparation of human resource planning is a necessity for a manager, and that a manager requires an analysis of the planning of human resource requirements itself.

\section{Job Qualifications and Roles}

The accomplishment of organizational objectives will be successful if the jobs within the organization are able to perform their duties as a fundamental component of the organizational structure. In an organization or business, qualifications or personnel specifications are a set of criteria that must be fulfilled by individuals who are deemed competent of doing particular positions within the organization.

\section{Analyze the Job}

In order to build or grow the organization, recruit employees, monitor their performance, train them, and process their paycheck, a job analysis must be conducted on each individual employee. Generally speaking, in order to analyze the work that will be assigned to potential workers, it is essential to know the substance of the job, the scope of work, as well as the qualifications for the position. It may be created and acquired from the three analyses via processes such as identifying tasks, determining activities in the workplace, determining knowledge, determining the abilities required, deciding skills, determining personality, attitudes, dexterity, and physical features.

Because of the strong connection between job classification and job analysis in human resource planning activities, job classification plays an essential role in job analysis (Human Resources).

\section{The purpose of a Job Analysis}

Job analysis is required in both the private and public sectors, and in both big and small-scale employment. Job analysis is required for a variety of reasons in both the private and governmental sectors. The following are some of the goals of job analysis: It includes information such as identifying information, a brief history of the company and its duties and responsibilities, specifications and standards. Job categorization is the process of grouping, classifying, and categorizing different kinds of labor in accordance with specific systematic designs. Evaluation of job functions is a method for classifying jobs based on their usefulness both inside the company and in the relevant external labor market. Jobs are being designed and restructured, and attempts are being made to move and reorganize work activities in different organizations. Preparation of precise requirements or specifications for a project; preparation of personnel requirements or specifications. Workers' job performance is assessed in a methodical manner by supervisors, who use this information to make decisions about their future. Worker training is carried out only for the purpose of training. Mobility of Workers in Careers; Job analysis is required in order to enable worker mobility in careers, which involves the dynamics of specific job roles. Efficiency; A task is considered efficient if it involves the optimum integration of work processes and is supported by sound design in terms of the safety of equipment and other physical facilities, among other criteria. Workplace safety should be prioritized. Human Resources Planning is a crucial stage in the process of human resource planning. It is also necessary to do job analysis in order to develop laws or work standards that will ensure that the plans that have been developed are carried out as intended. 


\section{Coaching Process}

Following selection, there will be training. A worker is chosen or assigned to a position in the organization who requires further training. This enables him to carry out his responsibilities correctly and efficiently. Managers, in a similar vein, need training for advancement and personal development. Employees are now given with training immediately after their appointment, as well as on an as-needed basis subsequently. This course is intended to be used as a tool or method for executive management and/or professional development. It is used for the development of human resources in the field of work. To the contrary, in today's fast-paced corporate world, training is the watchword.

Training refers to the provision of information, knowledge, and education to workers in order to help them improve technical skills, social skills, and administrative capabilities. Education and training, according to Edwin Flippo, is "the process of improving an employee's knowledge and abilities to do a certain profession."

The duty for employee training falls on the shoulders of management. Investing in this kind of training is a smart long-term investment in the growth of your staff. Employees should take use of the training opportunities available to them in order to improve their efficiency as well as their personal growth. Training should not be seen as a punishment, but rather as a chance to learn, grow, and improve the profession to a greater degree of proficiency.

In addition to system design and implementation, personnel management include staff preparation, employee growth, career management, performance assessment, employee pay, and positive employee relations. Human resource management encompasses all management choices and procedures that have a direct impact on the organization's human resources.

\section{Management Challenges during the Covid 19 Pandemic}

Through this epidemic, we've learned that industry's duty is not just to absorb people, but also to develop and manage those individuals inside the business. Employee productivity was negatively affected by social constraints and the decrease in economic activity that occurred during the Covid-19 epidemic. In order to sustain the performance of the employees in this scenario, the company's human resources department must be as creative as possible.

As part of the Covid-19 pandemic response, which began in mid-March 2020, work activities in offices and other places of business are restricted in order to prevent the spread of a new form of corona virus. As a consequence, many employees are forced to quit their jobs or work from home in order to maintain their productivity. When it comes to adopting work from home, the company's primary emphasis is on increasing employee productivity while also improving their mental wellness.

Leaders should offer training to enhance the mental health of their workers, or at the very least establish a support group for individuals suffering from mental illnesses. The fact that thousands of workers are suffering from "mental health issues" as a result of this epidemic is widely reported in various nations. The reasons for this include, among other things, the loss of a source of income, the need to adjust to new work routines, and problems in meeting job objectives. The report recommends four essential measures to cope with crises in general, including reacting to crises in line with the urgency, communicating openly, responding productively to prevent mistakes, and keeping up with the latest information.

The management of a business must modify different policies and corporate performance objectives in light of changing circumstances, conditions, and opportunities. These policies and targets include flexible working hours, leave policies, overtime, work goals, and employee performance evaluations. A leader's ability to empathize with his or her workers is essential if 
he or she is to make the best choices. Leaders with a high level of compassion will provide a solid foundation for their organizations, ensuring that their subordinates have excellent mental health, are competent, are driven, and have positive values, thus increasing their participation in the organization's long-term survival. They will see the leader as someone in whom they can place their faith and respect, and as a result, the guidance and inspiration he provides will serve as a "guide" for them. Leaders who are not easily disheartened, who have strong spiritual and emotional intelligence, and who are able to encourage subordinates to innovate and pursue successful breakthroughs are required in this epidemic scenario. As a result, businesses that are significantly impacted by the pandemic scenario must work hard and quickly to achieve breakthroughs. As a consequence of the COVID-19 epidemic, businesses are being compelled to downsize their workforces. Management is often compelled to dismiss daily workers and not renew contract employees due to a variety of factors, leaving individuals with more potential and employees who are more senior and competent. During a pandemic such as the one we are seeing now, everyone from upper management to the lowest levels of workers will be concerned about the uncertain future. Workers will get even more anxious if they learn that a large number of employees are being fired at the same time. Greater time will allow them to devote more attention to them. Pay attention to the challenges that were faced in finishing the job in the face of restricted resources. If they work from home, give them with office supplies and equipment that will make their jobs easier, such as credit for communication and laptops with fresh batteries to make their lives easier. In a scenario like this, the first difficulty for human resource professionals is to be able to give compelling information to workers regarding the evolution of the situation in the business while also maintaining contact with them

\section{Conclusion}

Firms that have been severely harmed by this pandemic scenario must work hard and quickly to find new ways to improve their operations. As a consequence of the COVID-19 epidemic, businesses are being compelled to downsize their workforces. In a scenario like this, the first difficulty for human resource professionals is to be able to give compelling information to workers regarding the evolution of the situation in the business while also maintaining contact with them. Greater time will allow them to devote more attention to them. Pay attention to the challenges that were faced in finishing the job in the face of restricted resources. If they work from home, make sure they have the necessary office equipment and supplies.

\section{References}

Amah, E., \& Ahiauzu, A. (2013). Employee involvement and organizational effectiveness. Journal of Management Development.

Armstrong, M. (2006). Strategic Human Resource Management-A Guide to Action 3rd Ed.

Autry, C. W., \& Daugherty, P. J. (2003). Warehouse operations employees: linking personorganization fit, job satisfaction, and coping responses. Journal of Business Logistics, 24(1), 171-197.

Barnett, R., \& Davis, S. (2008). Creating greater success in succession planning. Advances in developing human resources, 10(5), 721-739.

Brundage, H., \& Koziel, M. (2010). Retaining top talent still a requirement for firms: focus on people now to keep turnover costs down when the economy improves. Journal of Accountancy, 209(5), 38.

Compton, R. L. (2009). Effective recruitment and selection practices. CCH Australia Limited.

DeCenzo, D. A., Robbins, S. P., \& Verhulst, S. L. (2016). Fundamentals of human resource management. John Wiley \& Sons. 
Ekwoaba, J. O., Ikeije, U. U., \& Ufoma, N. (2015). The Impact of Recruitment and Selection Criteria on Organizational Performance.

Jiang, K., Lepak, D. P., Hu, J., \& Baer, J. C. (2012). How does human resource management influence organizational outcomes? A meta-analytic investigation of mediating mechanisms. Academy of management Journal, 55(6), 1264-1294.

Lumpkin, G. T., Cogliser, C. C., \& Schneider, D. R. (2009). Understanding and measuring autonomy: An entrepreneurial orientation perspective. Entrepreneurship theory and practice, 33(1), 47-69. 